\title{
НАЦИОНАЛЬНЫЕ СТРУКТУРЫ ПО ИМПЛЕМЕНТАЦИИ
}

\section{І. ВСТУПЛЕНИЕ}

Чем обусловлена необходимость создания национальных структур по имплементации международмого гуманитарного права?

Bce четыре Женевские Конвенции и Дополнительный Протокол I начинаются со следующих слов: “Стороны обязуются при любых обстоятельствах соблюдать и заставлять соблюдать настояцую конвенцию".

Таким образом, этими словами каждая из четырех конвенций определяет основную обязанность сторон - выполнять свои обязательства (статья 1, общая для четырех Женевских конвенций). Первый Дополнительный Протокол в статье 80 дополняет этот принцип. Эта статья предусматривает в четкой форме обязательство договаривающихся сторон и сторон, которые принимают участие в вооруженном конфликте, принимать все необходимые меры не только по выполнению положений Конвенций и Протоколов, но и по контролю за осуществлением этих мер.

Иными словами, все государства-участники Женевских конвенций и Дополнительных протоколов должны принимать все необходимые меры для того, чтобы в случае вооруженного конфликта они смогли сами соблюдать все положения этих договоров и обеспечивать их соблюдение на своей территории.

Меры, которые должны принять государства для имплементации международного гуманитарного права на национальном уровне, охватывают широкий диапазон проблем и действий. Некоторые из них требуют введения в действие национального законодательства, например, в том, что касается наказаний за серьезные нарушения международного гуманитарного права или защиты эмблемы красного креста или красного полумесяца. Другие меры носят чисто организационный, практический характер, например, когда речь идет о создании организации гражданкой обороны или о распространении знаний о международном гуманитарном праве.

Итак, как мы видим, процесс имплементации международного гуманитарного права - это всесторонний процесс, который затрагивает различные сферы и различные государственные органы. В этой связи возникает настоятельная необходимость координации усипий различных органов власти в области имплементации международного гуманитарного права.

Учитывая сложность этого процесса, Международный Комитет Красного Креста (MKKK) рекомендовал государствам-участникам Женевских конвенций и Дополнительньх Протоколов создать межведомственные комиссии по имплементации международного гуманитарного права.

По имеющейся у МККК информации, уже около 40 государств создали подобные структуры. Среди государств-членов Содружества Независимых Государств такие органы созданы в Республике Беларусь, Грузии, Молдове, Киргызской Республике и Таджикистане. В ходе XVII Международной конференции Красного Креста и Красного Полумесяца Российская Федерация обязалась изучить вопрос о создании подобной структуры, а Украина - создать таковую. Кроме того, в настоящее 
время рассматривается вопрос о создании Комиссии по имплементации международного гуманитарного права в Армении и Узбекистане.

Безусловно, что все эти органы в разных странах отличаются друг от друга. Их структура, устав, полномочия и деятельность зависят от характера внутреннего законодательства, конституционных основ государственной власти и т. д.

Следует обратить внимание на то, что не существует единой модели такого органа, так как конкретные вопросы создания, структуры и полномочий такого органа зависят только от решения самого государства с учетом его внутренней системы.

\section{2. ОБЗОР СУЩЕСТВУЮЩИХ СТРУКТУР И/ИЛИ ОРГАНОВ}

На базе имеюшейся информации по сорока созданным Комиссиям, можно сделать краткий обзор основных характерных черт органов.

\section{1 Виды органов}

Некоторые органы действуют на постоянной основе, другие создаются ad hoc для выполнения конкретных задач и прекращают свое сушествование после того, как эти задачи выполнены. Очевидно, что было бы желательным, чтобы данные структуры функционировали на постоянной основе.

По имеющейся у МККК информации, среди действуюших структур можно выделить, например, следуюшие их виды:

- комиссии, комитеты, рабочие группы межведомственного характера;

- комиссии или комитеты, которые получили правительственный мандат и были созданы в рамках Национальных обществ Красного Креста или Красного Полумесяца.

- национальные комиссии по правам человека, мандат которых расширен в отношении вопросов международного гуманитарного права, или которые решают отдельные вопросы и в этой области.

\section{2 Способы создания таких органов и их статус}

Способы создания подобных органов и их статус зависят от конституционной структуры и процедуры, действующей в том или ином государстве. В большинстве случаев комиссии, комитеты или рабочие группы постоянного характера создаются на основе закона или президентского или правительственного акта.

Министерства, при которых созданы такие органы, различаются в зависимости от страны. Чаще всего это Министерство иностранных дел, Министерство обороны или Министерство юстиции.

Как правило, такие органы обладают консультативными функциями в рамках своих полномочий в области гуманитарного права.

По имеющейся у МКKК информации, ни один такой орган не создан при законодательной или судебной власти.

\section{3 Состав}

Комиссии и другие существующие национальные органы, как правило, включают в себя представителей министерств, деятельность которых связана с гуманитарным правом (министерства иностранных дел, 
обороны, внутренних дел, юстиции, здравоохранения, социального обеспечения, образования и т. д.). Часто встречается, что в состав таких органов входят в качестве постоянных членов или наблюдателей представители законодательной и судебной власти, равно как и эксперты (юристы, медики, преподаватели, военные и т. д.). Практически во всех случаях Национальное общество Красного Креста или Красного Полумесяца входит в состав такого органа или участвует в его деятельности.

\section{4 Полномочия и сфера деятельности}

Комиссии и другие органы, известные MKKK, обладают различным мандатом. Они могут обладать очень широкими полномочиями в различных сферах, связанных с гуманитарным право или, напротив, их деятельность может быть ограничена выполнением одной задачи в одной области гуманитарного права. Полномочия органов, действующих на постоянной основе, как правило, шире, чем у органов ad hoc. Безусловно, было бы желательным предоставить таким органам более широкие полномочия. При этом не вызывает сомнения тот факт, что полномочия и сфера деятельности этих органов зависит от участия государства в договорах по международному гуманитарному праву и от принятых (или принимаемых) мер по имплементации.

Подобные органы могут заниматься всем спектром проблем, связанных с гуманитарным правом. Это могут быть консультации по вопросам, связанным с участием в международных договорах по гуманитарному праву. Это может быть изучение конкретных вопросов, разработка мер по имплементации (законодательного, регламентарного и практического характера). Отдельные структуры могут быть заняты исключительно распространением знаний о международном гуманитарном праве и подгтовкой квалифицированного персонала в этой области (врачи, военные, преподаватели и т. д.).

Некоторые органы со временем стали действенными консультативными органами Министерства иностранных дел и/или Министерства обороны по всем вопросам, связанным с международным гуманитарным правом.

\section{5 Захлючение}

Создание Комиссии по имлементации международного гуманитарного права может явиться полезным и важным шагом в обеспечении всесторонней реализации норм международного гуманитарного права. Учреждение такого органа не предписывается Женевскими конвенциями или Дополнительными протоколами. Его образование. функции и состав полностью определяются государством, которое создает такой орган.

Важно также подчеркнуть, что полномасштабная имплементация международного гуманитарного права представляет собой непрерывный процесс и не завершается простым принятием законов и постановлений. В связи с этим, очень важно, чтобы такой орган работал на постоянной основе, а не был бы временным.

\section{3. ПРИМЕР БЕЛЬГИЙСКОЙ КОМИССИИ ПО ИМПЛЕМЕНТА- ЦИИ ГУМАНИТАРНОГО ПІРАВА}

В Бельгии в 1987 году по решснию Совета министров была создана Межведомственная комиссия по гуманитарному праву. В данной комиссии 
представлены различные министерства и ведомства, в частности, представители премьер-министра, Министерства юстиции, финансов, внешних сношений, обороны, здравоохранения, национального обшества Красного Креста. За время своей деятельности Комиссия добилась отличных результатов. В частности, создан институт советников по международному гуманитарному праву в вооруженных силах, принят ряд законов, в подготовке которых Комиссия приняла непосредственное участие, в частности, Закон 1993 года о пресечении серьезных нарушений права войны. С 1994 года Комиссия кроме того выполняет функции постоянного консультативного органа, который оказывает правительству помощь в области применения и дальнейшего развития международного гуманитарного права.

Бельгийская комиссия осушествляет свою деятельность, применяя исключительно эффективные методы работы.

\section{4. ОСНОВНЫЕ ПРИНЦИПЫ ДЕЯТЕЛЬНОСТИ НАЦИОНАЛЬ- НОЙ СТРУКТУРЫ ПО ИМПЛЕМЕНТАЦИИ МЕЖДУНАРОДНОГО ГУМАНИТАРНОГО ПРАВА}

На базе опыта, накопленного различными странами, МКKК выработал отдельные принципы, которым рекомендуется следовать при создании Комиссии или иной структуры по имплементации международного гуманитарного права.

\section{А. Статус и структура}

1. Поскольку имплементация международного гуманитарного права относится к сфере компетенции правительства, национальный орган по вопросам международного гуманитарного права, должен быть официально связан с исполнительной властью. Его юридический статус будет зависеть от конституционного устройства соответствуюшего государства и применяемых в нем процедур.

2. Обеспечение соблюдения международного гуманитарного права, в частности, имплементации этого права в масштабах государства являются постоянными задачами. Национальный орган, на который возлагаются задачи, связанные с международным гуманитарным правом, должен иметь постоянную структуру, что позволит ему лучше обеспечить непрерывность в выполнении его задач.

\section{Б. Полномочия и фунпини}

3. Конкретный национальный орган, работающий в области международного гуманитарного права, должен обладать полномочиями в области содействия соблюдению этого права, предоставления консультаций и координации во всех вопросах применения на внутригосударственном уровне, обеспечения соблюдения и развития этого права. Полномочия и состав этого органа должны быть четко определены и могут быть впоследствии выражены либо в учредительном документе, либо в ином положении.

Этот орган должен быть уполномочен:

\section{- Оиенивать}

Быть в состоянии изучить и оценить состояние внутреннего законодательства, судебных и административных постановлений в свете обяза- 
тельств, вытекающих из Женевских Конвенций 1949 г. и, в соответствующих случаях, из Дополнительных Протоколов к ним 1977 г., а также других документов гуманитарного права.

\section{- Предлагать}

Быть в состоянии представлять соответствуюшим властям консультативные заключения по вопросам, связанным с имплементаџией гуманитарного права, и составлять рекомендации и предложения в данной области. Для этого необходимо обладать правом законодательной инициативы.

Эти заключения и рекомендации могут касаться, в частности, следуюших проблем:

- включение положений гуманитарных договоров во внутригосударственное право;

- разработка всех необходимых законодательньх, инструктивных или алминистративньх мер, которые позволили бы эффективно применять нормы гуманитарного права и, следовательно соблюдать эти нормы;

- принятие, в частности, законодательных актов, которые обеспечивали бы наказание за серьезные нарушения этого права и зашиту эмблемы красного креста и красного полумесяца, равно как и других сигналов, которые должны пользоваться аналогичной защитой;

- принятие нормативных актов, определяющих и гарантируюших статус лиц; на которых распространяется зашита международного гуманитарного права, и обеспечивающие уважение к личности и судебные гарантии во время вооруженного конфликта;

- подготовка и назначение персонала, обладаюшего квалификацией в области гуманитарного прав, в частности юридических советников в вооруженных силах;

- размешение и обозначение объектов и ценностей, пользующихся защитой гуманитарного права.

\section{- Контролировать}

Контролировать практическое применение сделанных им рекомендаций и вводов.

- Поддерживать, координировать и приводить в соответствие

Оказывать поддержку тем, кто работает в данной области, в частности представителям различных министерств и ведомств, поощрять сотрудничество между ними и оказывать им помощь в этом сотрудничестве, при необходимости координировать их деятельность. Служить катализатором в отношениях между соответствующими политическими и социальными силами.

\section{- Консультировать}

Выполнять любые другие задачи, которые могут быть доверены ему правительством в том, что касается гуманитарного права и давать заключения по всем касающимся этой отрасли права вопросам, которые могут быть ему направлены.

\section{- Распространять знания и информацию о гуманитарном праве}

Играть важную роль в распространении знаний о международном гуманитарном праве и обладать полномочиями, необходимыми для проведения исследований, внесения предложений относительно видов деятельности по распространению знаний и участия в такой деятельности. 
Он должен также участвовать в разработке программ по обучению международному гуманитарному праву в вооруженных силах и силах поддержания порядка, а также по обучению этому праву других гражданских или военных властей, которые должны взять на себя обязательства по применению МГП, а также по его преподаванию на всех уровнях школьного и профессионального образования, включая высшее.

\section{B. Состав}

4. Чтобы национальный орган, работаюший в области гуманитарного права, мог справляться с возложенными на него задачами, он должен обладать следующими характеристиками:

\section{- Представительность}

В его составе должны быть представлены все подразделения правительства, имеющие отношение к гуманитарному праву, среди его членов должны быть, в частности, представители исполнительной, судебной и законодательной властей, обладающие полномочиями привлекать к работе те органы власти, которые они представляют.

- Взаимодействие с национальными обществами Красного Креста и Красного Полумесяца

Привлекать национальное общество Красного Креста или Красного Полумесяца к участию в своей деятельности на основании той роли, которая отводится таким обществам договорами по гуманитарному праву и Уставом Международного движения Красного Креста и Красного Полумесяца, а также на том основании, что оно обладает знаниями и опьтомм в гуманитарной области.

\section{- Привлечение специалистов}

Заложить в механизм своей деятельности возможность получения консультаций у специалистов (юристов, врачей, преподавателей высшей школы, военных), а также представителей гражданского обшества (профессиональных ассоциаций, неправительственных организаций и т. д.) и привлечение таких специалистов и представителей к своей работе.

\section{Г. Формы работы}

5. В своей деятельности национальный орган, работаюший в области международного гуманитарного права, должен отвечать следующим критериям:

\section{- Непрерывность и регулярность работы}

Обеспечение непрерывности в выполнении задач, связанных с международным гуманитарным правом, с тем, чтобы проблемы этого права оставались в повестке дня правительства; организовать свою структуру и деятельность так, чтобы обеспечить эту непрерывность.

Проводить заседания настолько часто, насколько в этом возникает необходимость, и, по возможности, регулярно; на заседаниях должны присутствовать все регулярно вызываемые члены.

- Упорядоченный характер работы

Определить порядок работы; составить таблицу областей, в которых необходимо принятие мер по имплементации МГП, определить эти области, а также соответствующие органы власти; определить план действий и установить приоритеты. 
Проводить работу на пленарных заседаниях или поручать выполнение некоторых видов деятельности отдельным членам или подкомитетам.

- Представление отчетов

Регулярно отчитываться о проделанной работе перед правительством и другими заинтересованными органами.

- Наличие необходимых средств

Иметь в своем распоряжении сотрудников, а также материальные и финансовые ресурсы, необходимые для выполнения поставленных перед ним задач.

\section{Д. Сотрудничество}

6. Желательно, чтобы между национальными органами, действуюшими в области международного права, происходили регулярные контакты и было установлено сотрудничество, поскольку указанным органам нередко приходится решать сходные вопросы и проблемы. Для этого орган, работающий в области международного гуманитарного права должен:

- Осуществлять обмен информацией и сотрудничество

ПОддерживать связи и обмен информацией относительно своей деятельности и накопленного опыта с органами подобного рода, работающими в странах того же региона или со сходными юридическими системами; организовывать совместную деятельность с этими органами и/или приглашать специалистов этих органов для участия в своей деятельности.

Развивать регулярные контакты с другими учреждениями, которые участвуют или заинтересованы в имплементации гуманитарного права, и с Консультативной службой Международного Комитета Красного Креста.

\section{- Ннформировать}

Регулярно информировать Консультативную службу по вопросам международного гуманитарного права Международного Комитета Красного Креста и, в частности, сообщать ей обо всех происходящих в государстве событиях, связанных с гуманитарным правом.

\section{- Проводить встречи}

Проводить встречи между органами одного вида на межгосударственном и региональном уровнях; искать с этой целью поддержки на региональных и всемирных форумах.

Отдел по имплементации международного гуманитарного права, Московская региональная делегация МКKK.

Статья поступила в редакцию в январе 20002. 